\title{
OPEN Effects of fertilizer practice on fungal and actinobacterial cellulolytic community with different humified particle-size fractions in double-cropping field
}

\author{
Haiming Tang ${ }^{1,3 凶},{\text { Chao } \mathrm{Li}^{1,3}, \text { Yilan } \mathrm{Xu}^{2 \bowtie}, \text { Kaikai Cheng }}^{1}$, Lihong Shi ${ }^{1}$, Li Wen ${ }^{1}$, Weiyan $\mathrm{Li}^{1}$ \&
} Xiaoping Xiao ${ }^{1}$

Cellulose plays an important role in maintaining or improving soil carbon (C) cycling and soil fertility of paddy field. There had close relationship between functional cellulose genes (cbhl and GH48) with characterize of soil organic matter chemical components (fulvic acid and humic acid) and soil physical fractions. However, there is still limited information about how functional cellulose degradation response to long-term fertilizer management and their relative importance for $C$ sequestration under the double-cropping rice paddy field in southern of China. Therefore, the objective of this study were investigated the effects of 34-years long-term fertilizer regime on community abundance of $c b h /$ and GH48 genes in five soil particle-size fractions ( $2000 \mu \mathrm{m}, 2000-200 \mu \mathrm{m}, 200-50 \mu \mathrm{m}, 50-2 \mu \mathrm{m}$ and 2-0.1 $\mu \mathrm{m}$ ) by using polarization magic angle spinning ${ }^{13} \mathrm{C}$ nuclear magnetic resonance spectroscopy. The field experiment was included four different fertilizer treatments: chemical fertilizer alone (MF), rice straw and chemical fertilizer (RF), $30 \%$ organic manure and $70 \%$ chemical fertilizer (OM), and without fertilizer input as a control (CK). The results showed that distribution of soil humus and cellulolytic microbial community abundance was significant increased under long-term application of crop residue and organic manure condition. And the FA, HA and HM C contents in $>2000 \mu \mathrm{m}$ and 2000$50 \mu \mathrm{m}$ fractions with MF, RF and OM treatments were significant higher than that of CK treatment. Meanwhile, the alkyl C and Oalkyl C groups of FA and HA in $>2000 \mu \mathrm{m}$ fraction with MF, RF, OM and CK treatments were higher than that of the other fractions. There had higher AL\% and lower ARO\% of FA and $\mathrm{HA}$ in different particle-size fractions with MF, RF, OM and CK treatments. The results indicated that abundance of $c b h l$ and $G H 48$ genes in different particle-size fractions with RF and OM treatments were significant increased, compared with $\mathrm{CK}$ treatment. There had significant positive correlation between soil humus $C$ components (FA and HA) with abundance of $c b h l$ and $G H 48$ genes, and the o-alkyl C and AL\% of FA were positively correlated with abundance of $c b h l$ and $G H 48$ genes. As a result, the community abundance of $c b h /$ and $\mathrm{GH} 48$ genes were significant increased under combined application of crop residue and organic manure with chemical fertilizer condition.

Soil organic matter (SOM) is a general term for series of organic compounds formed by various organic substances entering the soil under the action of soil microorganism, it plays a vital role in maintaining or improving soil quality and productivity ${ }^{1}$. Furthermore, agricultural soil is the main source of greenhouse gas emission, which is benefit for mitigating global climate warming by increased carbon $(\mathrm{C})$ sequestration in agricultural soil and decreased carbon dioxide $\left(\mathrm{CO}_{2}\right)$ emission into atmospheric ${ }^{2}$. Some results indicated that higher SOM content can improve soil quality and represent a substantial contribution to reduction of $\mathrm{CO}_{2}$ emission via $\mathrm{C}$ sequestration ${ }^{3}$. Therefore, it is beneficial practice for maintaining or improving soil quality and productivity by increased SOM content.

${ }^{1}$ Hunan Soil and Fertilizer Institute, Changsha 410125, China. ${ }^{2}$ Hunan Biological and Electromechanical Polytechnic, Changsha 410127, China. ${ }^{3}$ These authors contributed equally: Haiming Tang and Chao Li. ${ }^{\boxplus}$ email: tanghaiming66@163.com; 229280200@qq.com 
SOM content and quality were close related with different particle-size fractionation of soil. Particle-size fractionation, which allows for the separation of SOM pool with changing degrees of microbial alteration and mineral association, might help elucidate microbial-mediated soil $\mathrm{C}$ cycling characteristic ${ }^{4,5}$. In the previous studies, these results indicated that SOM were mostly derived from the decomposition of animal and plant litter, soil humus component were main affected by environmental change, such as soil type ${ }^{6}$, crop system $^{7}$, fertilizer regime $^{8}$ and so on. Soil humus is a complex organic matter, which the animal and crop residue were synthesized by soil microbial decomposition and transformation. Soil humus are main including of fulvic acid (FA), humic acid (HA) and humin (HM), which are the most ubiquitous non-living natural organic compounds in the soil ${ }^{9}$. However, there is still limited information about how the soil particle-size fractions respond to chemical and spectroscopic characteristics of soil humus under long-term fertilization condition.

Soil humification is the main process of soil C cycling with microbial-mediated, and cellulose decomposition is the critical process of soil $\mathrm{C}$ transformation for that cellulose is the most abundant polysaccharide in plant litter that enters soil ${ }^{10}$. In the previous studies, the results indicated that decomposition of cellulose was main completed through the synergistic activity of three major groups of soil enzyme, such as endoglucanases, cellobiohydrolases and $\beta$-glucosidases ${ }^{11}$. During the rate-limited step of cellulose decomposition, cellulolytic enzyme were main encoded by fungal glycoside hydrolase family 7 cellobiohydrolase I gene $(c b h I)$ and bacterial glycoside hydrolase family $48(\mathrm{GH} 48)^{12}$. In recent years, some results indicated that fungal cbhI in Ascomycota and Basidiomycota could representative group of cellulolytic fungi ${ }^{13,14}$, and the abundance and diversity of GH48 gene were detected from actinobacteria could representative ecological role in soil $\mathrm{C}$ cycling ${ }^{15}$. Therefore, it was benefit for explanting of $\mathrm{C}$ transformation mechanism to investigate of the key functional gene corresponding to specific soil microorganism involved in cellulose decomposition under long-term fertilization condition ${ }^{16,17}$.

Rice (Oryza sativa L.) is one of the main crops in Asia, and double-cropping rice system (early rice and late rice) is the main land use in southern of China ${ }^{18}$. It is benefit practice for maintaining or improving quality and fertility of paddy field by combined application of organic fertilizer with inorganic fertilizer ${ }^{2,18}$. Soil physical and chemical characteristics were profound changed by taken different fertilizer management, such as $\mathrm{pH}$, soil bulk density, soil organic carbon (SOC) content ${ }^{18}$, which in return affecting functional humus fractions and C sequestration in paddy field. In the previous studies, these results indicated that soil functional humus fractions and SOC content were usually regarded as a vital index for the change of soil quality and fertility ${ }^{1,9}$, and soil fungal and actinobacterial cellulolytic community plays an important role in processing of $C$ transformation in paddy filed $^{11,15}$. However, there is still need further to study the effects of different fertilizer management on fungal and actinobacterial cellulolytic community in different humified particle-size fractions in the double-cropping rice paddy field under long-term fertilization condition. We hypothesized that: (i) chemical and structural characteristics of soil humus would be changed under long-term fertilization condition; (ii) fungal and actinobacterial cellulolytic community abundance would be influenced by fertilization, particle-size fraction and their interaction effects, and (iii) correlation between cellulolytic microbial abundance with $\mathrm{C}$ content of soil humus were also changed under long-term fertilization condition. Therefore, the 34-years long-term field experiment with different fertilizer treatments were conducted in a double-cropping rice system in the southern of China. Hence, the objective of this study was: (1) to illustrate the chemical and structural characteristics of soil humus (FA, HA and $\mathrm{HM}$ ) in different fertilizer practice under a double-cropping rice system; (2) to investigate the abundance of $c b h I$ and GH48 genes in five particle-size fractions $(>2000 \mu \mathrm{m}, 2000-200 \mu \mathrm{m}, 200-50 \mu \mathrm{m}, 50-2 \mu \mathrm{m}$ and $2-0.1 \mu \mathrm{m})$ in paddy field under long-term fertilization condition.

\section{Materials and methods}

Sites and cropping system. The experiment was begun in 1986. It was located in NingXiang County $\left(28^{\circ} 07^{\prime} \mathrm{N}, 112^{\circ} 18^{\prime} \mathrm{E}\right)$ of Hunan Province, China. The field experiment under a continental monsoon climate, the annual mean precipitation is $1553 \mathrm{~mm}$ and potential evapotranspiration is $1354 \mathrm{~mm}$. The monthly mean temperature is $17.2 \mathrm{C}$. At beginning of this field experiment, the soil chemical characteristics at plough layer $(0-20 \mathrm{~cm})$ of paddy field were as follows: soil organic carbon (SOC) $29.4 \mathrm{~g} \mathrm{~kg}^{-1}$, total nitrogen (N) $2.0 \mathrm{~g} \mathrm{~kg}^{-1}$, available $\mathrm{N} 144.1 \mathrm{mg} \mathrm{kg}^{-1}$, total phosphorous (P) $0.59 \mathrm{~g} \mathrm{~kg}^{-1}$, available $\mathrm{P} 12.87 \mathrm{mg} \mathrm{kg}^{-1}$, total potassium (K) $20.6 \mathrm{~g} \mathrm{~kg}^{-1}$, and available $\mathrm{K} 33.0 \mathrm{mg} \mathrm{kg}^{-1}$. The crop rotation system and other more detail information about the field experiment were described as by Tang et al. $(2018)^{19}$.

\section{Experimental design}

The field experiment was included four fertilizer treatments: chemical fertilizer alone (MF), rice straw and chemical fertilizer (RF), 30\% organic manure and 70\% chemical fertilizer (OM), and without fertilizer input as a control (CK). A randomized block design was adopted in the plots, with three replications of each treatment. And each plot size was $66.7 \mathrm{~m}^{2}(10.0 \times 6.67 \mathrm{~m})$. The field experiment were ensured that same total amount of $\mathrm{N}$, phosphorus pentoxide $\left(\mathrm{P}_{2} \mathrm{O}_{5}\right)$, potassium oxide $\left(\mathrm{K}_{2} \mathrm{O}\right)$ for $\mathrm{MF}, \mathrm{RF}$ and $\mathrm{OM}$ treatments during early rice and late rice whole growth period, respectively. During the early rice and late rice whole growth period, the total amount of $\mathrm{N}, \mathrm{P}_{2} \mathrm{O}_{5}, \mathrm{~K}_{2} \mathrm{O}$ for MF, RF and OM treatments were $142.5,54.0,63.0 \mathrm{~kg} \mathrm{ha}^{-1}$ and $157.5,43.2,81.0 \mathrm{~kg} \mathrm{ha}^{-1}$, respectively. And the kind of organic manure for OM treatment was decomposed chicken manure. The kinds of chemical fertilizer were included urea, ordinary superphosphate, and potassium chloride, respectively. Before transplanting of rice seedling, air-dried rice straw were manually spread onto the soil surface and incorporated into the soil at a cultivation depth of $20 \mathrm{~cm}$. During early rice and late rice whole growth period, $70 \%$ and $60 \%$ of $\mathrm{N}$ were applied at tillage before transplanting of rice seedling, respectively, and the remaining $\mathrm{N}$ were applied at top dressing stage of rice. All the $\mathrm{P}_{2} \mathrm{O}_{5}$ and $\mathrm{K}_{2} \mathrm{O}$ fertilizer were applied at tillage before transplanting of rice seedling. One-month-old of early rice and late rice seedling were transplanted with the density of 150,000 plants 
$\mathrm{ha}^{-1}$ in paddy field. Other more detail information about fertilizer management and filed arrangement were described as by Tang et al. $(2018)^{19}$.

Soil sampling and samples preparation. There had ensured that permission to collect soil sampling in this experiment. Undisturbed soil samples were collected from each plot in 25 August, 2019, at the tillering stage of late rice. Three soil cores $(10 \times 10 \times 15 \mathrm{~cm})$ at the depth of $0-20 \mathrm{~cm}$ from each plot were collected and equally merged as representative soil samples for one replicate of each fertilizer treatment. Moist soil were gently broken apart along the natural breakpoints and passed through a 5-mm sieve to remove visible organic debris and crop root. After thorough mixing, different particle-size fractions were separated according to the method described as by Stemmer et al. ${ }^{20}$. In the present study, five particle-size fractions were obtained for each soil samples, such as $>2000 \mu \mathrm{m}, 2000-200 \mu \mathrm{m}, 200-50 \mu \mathrm{m}, 50-2 \mu \mathrm{m}$ and 2-0.1 $\mu \mathrm{m}$. These particle-size fractions were then stored at room temperature for analysis of soil chemical characteristic, at $4{ }^{\circ} \mathrm{C}$ for soil extracellular enzyme analysis and $80^{\circ} \mathrm{C}$ for the molecular analysis. The SOC, total nitrogen (TN) contents and soil enzyme activity ( $\beta$-glucosidase, $\beta$-cellobiohydrolase) of the soil samples were investigated according to the method described as by Zhang et al. ${ }^{21}$.

Soil laboratory analysis. Extraction and purification of soil humus. The extraction of different humus fractions from soil samples were performed with $5 \mathrm{~g}$ dry soil and $50 \mathrm{~mL}$ of $0.1 \mathrm{~mol} \mathrm{~L}^{-1} \mathrm{NaOH}$ in $0.1 \mathrm{~mol} \mathrm{~L}^{-1}$ so- $^{-}$ dium pyrophosphate under $\mathrm{a} \mathrm{N}_{2}$ atmosphere, and it were repeated several times until colorless supernatants were obtained. The suspensions were centrifuged at $5000 \times g$ for $15 \mathrm{~min}$ and the pooled alkali extract were acidified to $\mathrm{pH} 2.0$ with $\mathrm{H}_{2} \mathrm{SO}_{4}$, and kept for $24 \mathrm{~h}$ at room temperature. The soluble fulvic acid (FA) was separated from coagulation (humic acid (HA) fraction) by centrifugation ${ }^{9}$. The residue, which was the precipitate in the centrifuge tube, was collected to provide humin (HM). Total carbon (C) content of FA and HA were investigated by using multi $\mathrm{B} / \mathrm{C} 3100 \mathrm{TOC} / \mathrm{TN}$ and $\mathrm{C}$ content of $\mathrm{HM}$ were measured by using a vario macro cube element analyzer (Elementar Analysensysteme GmbH, Hanau, Germany). The soil C content of humus (FA, HA and HM) of the soil samples were investigated according to the method described as by Jindog et al. ${ }^{8}$.

CPMAS solid-state ${ }^{13}$ CNMR spectroscopy. In the present study, chemical composition of purified FA and HA fractions of soil samples with MF, RF, OM and CK treatments were via CPMAS solid-state ${ }^{13} \mathrm{CNMR}$ spectroscopy and expressed as the relative abundance of the major $C$ type. The solid-state ${ }^{13} \mathrm{CNMR}$ spectra were measured on a Bruker Avance III 400 NMR spectrometer (Germany) conducting at a spinning speed of $5 \mathrm{kHz}$ and a contact time of $1 \mathrm{~ms}$, with a ${ }^{1} \mathrm{H} 90{ }^{\circ} \mathrm{C}$ pulse length of $4 \mu$ s and a recycle delay of $0.8 \mathrm{~s}$. The chemical shift regions 0-45, 45-95, 95-165 and 165-200 ppm were referred to alkyl C, $o$-alkyl C, aromatic C and carboxylic C, respectively ${ }^{21}$. The areas of the spectral regions were measured though the integration routine of the spectrometer and expressed as percentage of the sum of all spectral areas, respectively ${ }^{22}$. The degree of aromaticity (ARO\%) and aliphaticity (AL\%) of the FA and HA C were calculated according to the equations as following:

$$
\begin{gathered}
\operatorname{ARO}(\%)=\frac{\text { Aromatic C }(95-165 \mathrm{ppm})}{\mathrm{C} \text { signal }(0-165 \mathrm{ppm})} \\
\mathrm{AL}(\%)=\frac{\text { Aliphatic } C(0-95 \mathrm{ppm})}{\mathrm{C} \text { signal }(0-165 \mathrm{ppm})}
\end{gathered}
$$

The alkyl C/o-alkyl C ratio were calculated and regarded as an indicator of the degree of organic matter decomposition $^{23}$.

Deoxyribonucleic acid (DNA) extraction and quantitative polymerase chain reaction ( $q P C R)$ assay. Soil DNA was extracted from $0.5 \mathrm{~g}$ fresh soil by using the FastDNA SPIN Kit (MP Biomedicals, Illkirch, France) and a Fast Prep-24 Homogenization System (MP Biomedicals, Irvine, CA) according to the manufacturer's instructions. Successful DNA extraction was characterized by using electrophoresis on $1 \%$ (wt/vol) agarose gels. The quantity and quality of DNA were checked by using Nanodrop spectrophotometer (Nanodrop, PeqLab, Germany).

Genes encoding fungal glycoside hydrolase family 7 cellobiohydrolase I gene $(c b h I)$ and bacterial glycoside hydrolase family 48 (GH48) were selected as biomarkers of cellulolytic fungi and actinobacteria, respectively. All qPCR assays were carried out in an iCycler system (Bio-Rad, USA) by using SYBR Green I chemistry and the data were analyzed by using Bio-Rad iQ5 v2.0, quantitative PCR were investigated according to the method described as by Fan et al. ${ }^{24}$.

Statistical analysis. The statistical analyses of each investigate items in this manuscript were conducted by using SAS 9.3 software package ${ }^{25}$. The data of each particle-size fractions with all fertilizer treatments in this manuscript were compared by using Fisher's significant difference at the $p<0.05$ probability level. Pearson's correlation analyses were performed to assess the linear correlation among soil properties, enzyme activity, $\mathrm{C}$ groups of FA and HA with abundance of $c b h I$ and $G H 48$ genes. The results of each investigate items were expressed as mean and standard error.

Statement on guidelines. There was not used live plant in the present experimental research and field study, and comply with relevant institutional, national, and international guidelines and legislation. 

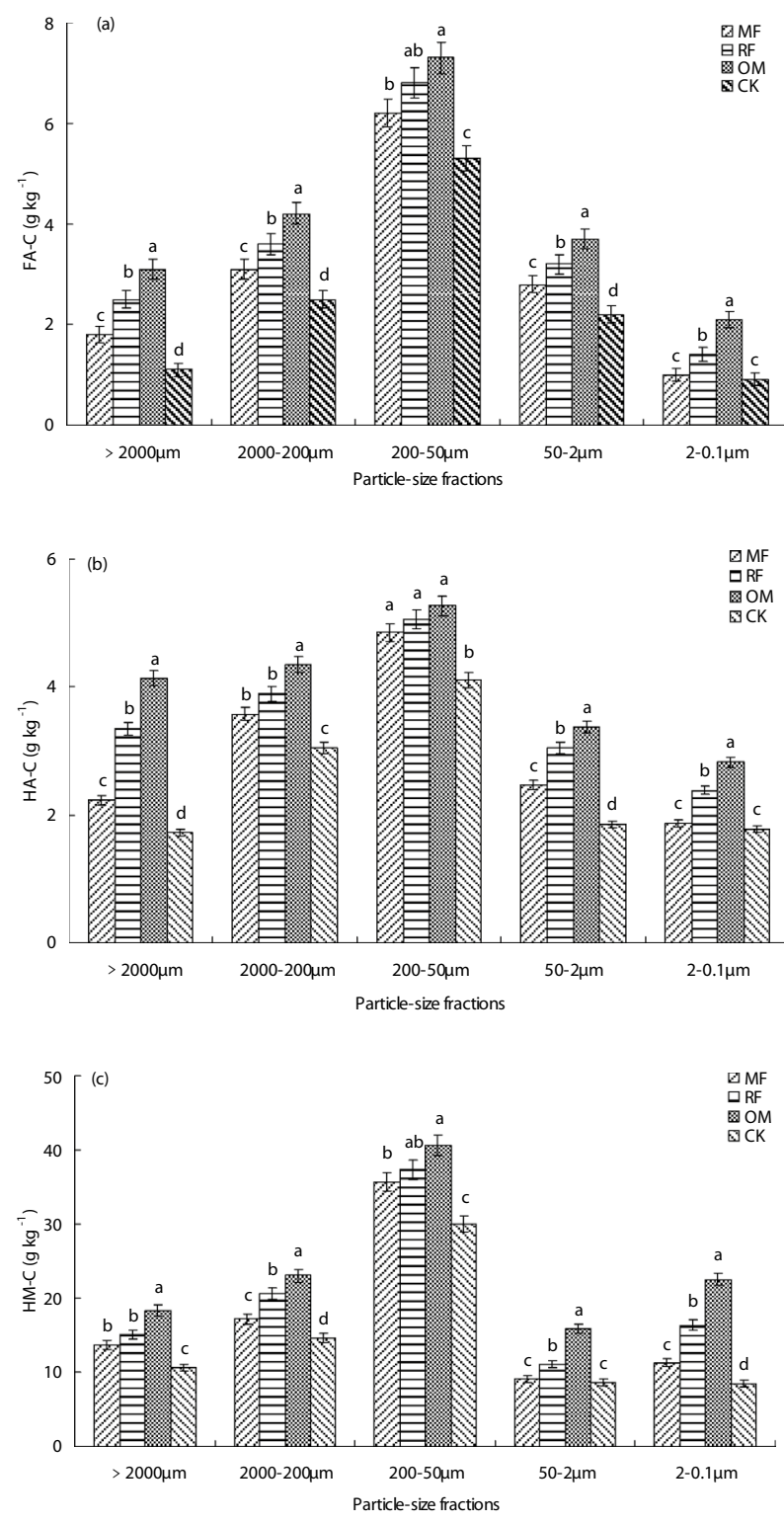

Figure 1. Carbon content of fulvic acid (FA), humic acid (HA) and humin (HM) from different particle-size fractions with different fertilizer treatments. $M F$ chemical fertilizer alone, $R F$ rice straw and chemical fertilizer, $O M 30 \%$ organic manure and $70 \%$ chemical fertilizer, $C K$ without fertilizer input as a control. (a) Carbon content of fulvic acid (FA-C), (b) carbon content of humic acid (HA-C), (c) carbon content of humin (HM-C). Different lowercase letters were indicated significant differences $(p<0.05)$ among different fertilizer treatments. Error bars represent standard error of the mean $(n=3)$.

\section{Results}

Carbon content of humus composition. In different particle-size fractions, the highest carbon (C) content of humus (FA, HA and HM) were found in 200-50 $\mu \mathrm{m}$ fraction, and the lower $\mathrm{C}$ content of humus were found in 50-0.1 $\mu \mathrm{m}$ fraction (Fig. 1a-c). Compared with MF treatment, the FA and HM C content in 2000-200 $\mu \mathrm{m}$ and 50-0.1 $\mu \mathrm{m}$ fractions with RF and OM treatments were significant $(p<0.05)$ higher (Fig. 1a,c), whereas there had not significant $(p>0.05)$ difference in HA C content in 200-50 $\mu \mathrm{m}$ fraction among MF, RF and OM treatments (Fig. 1b). The results indicated that FA, HA and HM C content in $>2000 \mu \mathrm{m}$ and $2000-$ $50 \mu \mathrm{m}$ fractions with MF, RF and OM treatments were significant $(p<0.05)$ higher than that of CK treatment. Particle-size fractions and fertilizer treatments were significant $(p<0.05)$ influence on distribution of humus $\mathrm{C}$ components (FA, HA and HM), but their interaction influence on HA C content were not significant $(p>0.05)$ difference (Table 1).

CPMAS solid-state ${ }^{13} \mathrm{C}$ NMR spectroscopy. The effects of different fertilizer treatments on humus $\mathrm{C}$ groups of FA and HA in five particle-size fractions were showed in Table 2. The results showed that alkyl C and 


\begin{tabular}{|l|l|l|l|l|l|r|}
\hline & \multicolumn{2}{|l|}{} & \multicolumn{2}{l|}{} & \multicolumn{2}{l|}{$\begin{array}{l}\text { Particle-size } \\
\text { fractions } \times \text { fertilizer }\end{array}$} \\
\cline { 2 - 8 } & $\boldsymbol{F}$ & $\boldsymbol{P}$ & $\boldsymbol{F}$ & $\boldsymbol{P}$ & $\boldsymbol{F}$ & \multicolumn{1}{|l|}{} \\
\hline FA-C & 86.52 & $<0.001$ & 84.26 & $<0.001$ & 3.56 & $<0.001$ \\
\hline HA-C & 91.67 & $<0.001$ & 61.58 & $<0.001$ & $\mathbf{1 . 6 2}$ & 0.135 \\
\hline HM-C & 80.47 & $<0.001$ & 70.24 & $<0.001$ & 3.27 & $<0.001$ \\
\hline Rice season & 84.26 & $<0.001$ & 72.04 & $<0.001$ & 4.63 & $<0.001$ \\
\hline cbhI abundance & 12.35 & 0.146 & 14.17 & 0.185 & $\mathbf{0 . 8 6}$ & 0.362 \\
\hline GH48 abundance &
\end{tabular}

Table 1. Two-way ANOVA analysis C content of soil humus, abundance of $c b h I$ and GH48 genes in the five soil particle-size fractions and fertilizer treatments. The data in bold were indicated the parameter were not significant affected by soil particle-size fractions, fertilizer treatments or their interaction $(p>0.05)$. FA-C carbon content of fulvic acid, $H A-C$ carbon content of humic acid, $H M-C$ carbon content of humin.

$o$-alkyl C groups of FA in $>2000 \mu \mathrm{m}$ fraction were significant higher $(p<0.05)$ than that of the other fractions (Table 2). However, carboxylic C of FA were most abundant in 50-2 $\mu \mathrm{m}$ and $2-0.1 \mu \mathrm{m}$ fractions, which were resulted in significant higher $\mathrm{ARO} \%$ of FA in these particle-size fractions. Aliphatic C of FA were most abundant in $>2000 \mu \mathrm{m}$ and $200-50 \mu \mathrm{m}$ fractions, which were resulted in significant higher AL\% of FA in these particle-size fractions. There had no obvious significant $(p>0.05)$ difference in proportion of aromatic $\mathrm{C}$ group among the five particle-size fractions and fertilizer treatments. The alkyl/o-alkyl C of FA in $200-50 \mu \mathrm{m}$ and $50-2 \mu \mathrm{m}$ fractions were significant lower $(p<0.05)$ than that of the other particle-size fractions.

The results indicated that alkyl $\mathrm{C}$ of HA were the highest in the five particle-size fractions, and carboxylic $\mathrm{C}$ of HA were the lowest in the five particle-size fractions (Table 2). Meanwhile, this result showed that there had higher $\mathrm{AL} \%$ and lower $\mathrm{ARO} \% \mathrm{C}$ of $\mathrm{HA}$ in different particle-size fractions. And the alkyl/o-alkyl C of $\mathrm{HA}$ were the lowest in 200-50 $\mu \mathrm{m}$ fraction and higher in 50-2 $\mu \mathrm{m}$ and 2-0.1 $\mu \mathrm{m}$ fractions with RF, MF and OM treatments.

Abundance of $c b h /$ and $\mathbf{G H 4 8}$ genes. In different particle-size fractions, the range of abundance of $c b h I$ gene with MF, RF, OM and CK treatments were 1.01-9.12 $\times 10^{7}$ copies $\mathrm{g}^{-1}$ soil (Fig. 2). The abundance of $c b h I$ gene were significant impacted by particle-size fractions and fertilizer treatments individually and interactively $(P<0.001$; Table 1). In different particle-size fractions, the abundance of $c b h I$ gene with MF, RF and OM treatments were significant higher $(p<0.05)$ than that of CK treatment. Furthermore, the abundance of $c b h I$ gene in different particle-size fractions with RF and OM treatments were significant higher $(p<0.05)$ than that of MF and CK treatments.

In different particle-size fractions, the range of abundance of GH48 gene with MF, RF, OM and CK treatments were $1.35-13.52 \times 10^{6}$ copies $\mathrm{g}^{-1}$ soil, which were about ten times lower than that of abundance of $c b h I$ gene (Fig. 3). This results indicated that abundance of $G H 48$ gene were obvious affected by particle-size fractions and fertilizer treatment individually, but there had no obvious significant $(p>0.05)$ affected by particle-size fractions and fertilizer treatment interactively (Table 1 ). The results showed that abundance of GH48 gene in 200-50 $\mu \mathrm{m}$ fraction were significant higher $(p<0.05)$ than that of the other fractions. In different particle-size fractions, the abundance of GH48 gene with MF, RF and OM treatments were significant higher $(p<0.05)$ than that of CK treatment. In $>2000 \mu \mathrm{m}, 2000-200 \mu \mathrm{m}$ and 200-50 $\mu \mathrm{m}$ fractions, the abundance of GH48 gene with $\mathrm{RF}$ and OM treatments were significant higher $(p<0.05)$ than that of MF and CK treatments. However, there had no significant $(p>0.05)$ differences in abundance of GH48 gene in 20-5 $\mu \mathrm{m}$ fraction between MF, RF, OM and CK treatments.

Correlation analysis. There had significant $(p<0.01)$ positive correlation between soil $\beta$-glucosidase and $\beta$-cellobiohydrolase activity with abundance of $c b h I$ and GH48 genes (Table 3). Meanwhile, the abundance of GH48 gene were significant $(p<0.01)$ correlated with soil properties (SOC, total N, and $\mathrm{C} / \mathrm{N}$ ) and soil humus C components (FA, HA and HM). And the abundance of $c b h I$ gene were significant $(p<0.01)$ correlated with soil $\mathrm{C} / \mathrm{N}, \mathrm{FA}$ and HA C components (Table 3 ).

Meanwhile, the results indicated that there had no significant $(p>0.05)$ relationship between alkyl $\mathrm{C}$ and aromatic C of FA with abundance of $c b h I$ and GH48 genes (Table 4). The C groups like o-alkyl C $(p<0.01)$ and AL\% of FA $(p<0.05)$ were positively correlated with abundance of $c b h I$ and GH48 genes, however, ARO $\%$ were negatively $(p<0.05)$ correlated with abundance of $c b h I$ and $G H 48$ genes. The results showed that both abundance of $c b h I$ and GH48 genes were negatively $(p<0.05)$ correlated with alkyl C, AL\%, alkyl/o-alkyl C of HA, but abundance of $c b h I$ and GH48 genes were positively $(p<0.05)$ correlated with aromatic C and ARO\% of HA (Table 4$)$.

\section{Discussion}

Soil organic matter (SOM) is a complex and heterogeneous mixture of various substances, which has a continuum of decomposition and stabilization process in the soil ${ }^{26}$. Humus carbon (C) content was representing a large portion of natural organic matter distributed under different environmental condition, such as soil, sediment and water ${ }^{27}$. In the present study, this results indicated that humus $\mathrm{C}$ were occupied main component of soil organic carbon (SOC), which were consistent with previous reported ${ }^{28}$, who found that identified compounds accounted 


\begin{tabular}{|c|c|c|c|c|c|c|c|c|}
\hline \multirow{2}{*}{$\begin{array}{l}\text { Particle-size } \\
\text { fractions }\end{array}$} & \multirow[b]{2}{*}{ Treatments } & \multirow{2}{*}{\begin{tabular}{|l|} 
0-45 ppm \\
Alkyl C \\
\end{tabular}} & \multirow{2}{*}{\begin{tabular}{|l|}
$45-95 \mathrm{ppm}$ \\
$O$-alkyl C \\
\end{tabular}} & \multirow{2}{*}{\begin{tabular}{|l|}
$95-165 \mathrm{ppm}$ \\
Aromatic C \\
\end{tabular}} & \multirow{2}{*}{\begin{tabular}{|l|}
$165-200$ ppm \\
Carboxylic C \\
\end{tabular}} & \multirow[b]{2}{*}{ ARO $\%$} & \multirow[b]{2}{*}{ AL\% } & \multirow[b]{2}{*}{ Alkyl/o-alky } \\
\hline & & & & & & & & \\
\hline \multicolumn{9}{|l|}{ FA } \\
\hline \multirow{4}{*}{$>2000 \mu \mathrm{m}$} & MF & $26.7 \pm 1.1 \mathrm{c}$ & $30.7 \pm 0.8 \mathrm{a}$ & $22.6 \pm 0.6 \mathrm{a}$ & $17.5 \pm 0.4 \mathrm{ab}$ & $28.25 \pm 0.84 \mathrm{a}$ & $71.75 \pm 2.02 b$ & $0.87 \pm 0.02 \mathrm{c}$ \\
\hline & RF & $30.6 \pm 0.9 \mathrm{~b}$ & $26.5 \pm 0.8 \mathrm{~b}$ & $20.9 \pm 0.6 \mathrm{ab}$ & $18.3 \pm 0.5 \mathrm{a}$ & $26.79 \pm 0.74 \mathrm{ab}$ & $73.21 \pm 2.14 \mathrm{a}$ & $1.15 \pm 0.04 \mathrm{~b}$ \\
\hline & $\mathrm{OM}$ & $32.5 \pm 0.8 \mathrm{~b}$ & $28.4 \pm 0.7 \mathrm{ab}$ & $20.4 \pm 0.5 b$ & $18.7 \pm 0.5 \mathrm{a}$ & $25.09 \pm 0.53 \mathrm{~b}$ & $74.91 \pm 2.11 \mathrm{a}$ & $1.14 \pm 0.04 \mathrm{~b}$ \\
\hline & CK & $38.6 \pm 0.7 \mathrm{a}$ & $18.5 \pm 0.5 c$ & $21.5 \pm 0.6 \mathrm{ab}$ & $16.3 \pm 0.3 b$ & $27.35 \pm 0.76 \mathrm{ab}$ & $72.65 \pm 2.06 \mathrm{ab}$ & $2.09 \pm 0.05 \mathrm{a}$ \\
\hline \multirow{4}{*}{$2000-200 \mu \mathrm{m}$} & MF & $18.5 \pm 0.5 \mathrm{~b}$ & $14.2 \pm 0.5 \mathrm{~b}$ & $23.1 \pm 0.6 \mathrm{a}$ & $40.5 \pm 1.1 \mathrm{a}$ & $41.40 \pm 1.24 \mathrm{a}$ & $58.60 \pm 1.55 \mathrm{~b}$ & $1.30 \pm 0.04 \mathrm{a}$ \\
\hline & $\mathrm{RF}$ & $20.1 \pm 0.5 \mathrm{ab}$ & $19.4 \pm 0.6 \mathrm{a}$ & $22.1 \pm 0.5 \mathrm{ab}$ & $36.7 \pm 1.0 \mathrm{ab}$ & $35.88 \pm 1.16 \mathrm{ab}$ & $64.12 \pm 1.81 \mathrm{ab}$ & $1.04 \pm 0.03 \mathrm{ab}$ \\
\hline & $\mathrm{OM}$ & $20.6 \pm 0.5 \mathrm{a}$ & $20.3 \pm 0.7 \mathrm{a}$ & $22.6 \pm 0.5 \mathrm{ab}$ & $35.4 \pm 0.9 \mathrm{~b}$ & $35.59 \pm 1.10 \mathrm{ab}$ & $64.41 \pm 1.87 \mathrm{ab}$ & $1.01 \pm 0.02 \mathrm{~b}$ \\
\hline & CK & $21.8 \pm 0.6 \mathrm{a}$ & $16.7 \pm 0.5 c$ & $20.7 \pm 0.4 \mathrm{~b}$ & $38.7 \pm 1.1 \mathrm{ab}$ & $34.97 \pm 0.96 \mathrm{~b}$ & $65.03 \pm 2.02 \mathrm{a}$ & $1.31 \pm 0.04 \mathrm{a}$ \\
\hline \multirow{4}{*}{$200-50 \mu \mathrm{m}$} & MF & $28.6 \pm 0.7 \mathrm{ab}$ & $28.5 \pm 0.7 \mathrm{~b}$ & $25.3 \pm 0.7 \mathrm{a}$ & $18.7 \pm 0.6 \mathrm{a}$ & $30.70 \pm 1.05 \mathrm{a}$ & $69.30 \pm 1.67 \mathrm{~b}$ & $1.00 \pm 0.03 \mathrm{a}$ \\
\hline & $\mathrm{RF}$ & $29.2 \pm 0.8 \mathrm{a}$ & $31.7 \pm 0.9 \mathrm{a}$ & $24.3 \pm 0.6 \mathrm{ab}$ & $17.6 \pm 0.5 \mathrm{ab}$ & $28.52 \pm 0.95 b$ & $71.48 \pm 1.78 \mathrm{a}$ & $0.92 \pm 0.02 \mathrm{~b}$ \\
\hline & OM & $29.6 \pm 0.8 \mathrm{a}$ & $32.4 \pm 0.9 \mathrm{a}$ & $24.7 \pm 0.6 \mathrm{ab}$ & $17.1 \pm 0.4 \mathrm{~b}$ & $28.49 \pm 0.91 \mathrm{~b}$ & $71.51 \pm 1.85 \mathrm{a}$ & $0.91 \pm 0.02 \mathrm{~b}$ \\
\hline & CK & $27.4 \pm 0.6 \mathrm{~b}$ & $30.3 \pm 0.8 \mathrm{ab}$ & $23.5 \pm 0.5 \mathrm{~b}$ & $18.2 \pm 0.6 \mathrm{a}$ & $28.94 \pm 0.97 b$ & $71.06 \pm 1.93 a$ & $0.90 \pm 0.02 \mathrm{~b}$ \\
\hline \multirow{4}{*}{$50-2 \mu \mathrm{m}$} & MF & $14.5 \pm 0.5 \mathrm{~b}$ & $21.6 \pm 0.6 \mathrm{a}$ & $26.4 \pm 0.8 \mathrm{a}$ & $42.3 \pm 0.9 \mathrm{~b}$ & $42.24 \pm 1.15 \mathrm{a}$ & $57.76 \pm 1.43 \mathrm{~b}$ & $0.67 \pm 0.01 \mathrm{~b}$ \\
\hline & $\mathrm{RF}$ & $14.1 \pm 0.4 \mathrm{~b}$ & $20.7 \pm 0.5 \mathrm{ab}$ & $25.1 \pm 0.7 \mathrm{ab}$ & $45.7 \pm 1.1 \mathrm{ab}$ & $41.90 \pm 1.03 \mathrm{~b}$ & $58.10 \pm 1.55 \mathrm{ab}$ & $0.68 \pm 0.01 \mathrm{~b}$ \\
\hline & OM & $13.6 \pm 0.3 c$ & $21.2 \pm 0.6 \mathrm{a}$ & $25.6 \pm 0.7 \mathrm{ab}$ & $46.8 \pm 1.2 \mathrm{ab}$ & $42.38 \pm 1.18 \mathrm{a}$ & $57.62 \pm 1.47 \mathrm{~b}$ & $0.64 \pm 0.01 \mathrm{~b}$ \\
\hline & $\mathrm{CK}$ & $15.2 \pm 0.5 \mathrm{a}$ & $20.1 \pm 0.4 \mathrm{~b}$ & $18.9 \pm 0.6 \mathrm{~b}$ & $51.6 \pm 1.3 \mathrm{a}$ & $34.87 \pm 0.96 \mathrm{c}$ & $65.13 \pm 1.68 \mathrm{a}$ & $0.76 \pm 0.02 \mathrm{a}$ \\
\hline \multirow{4}{*}{$2-0.1 \mu \mathrm{m}$} & MF & $26.5 \pm 0.7 \mathrm{ab}$ & $12.1 \pm 0.3 \mathrm{c}$ & $31.6 \pm 0.9 \mathrm{a}$ & $40.7 \pm 1.1 \mathrm{ab}$ & $45.01 \pm 1.32 \mathrm{a}$ & $54.99 \pm 1.35 \mathrm{~b}$ & $2.19 \pm 0.08 \mathrm{a}$ \\
\hline & $\mathrm{RF}$ & $27.1 \pm 0.7 \mathrm{ab}$ & $16.6 \pm 0.5 \mathrm{a}$ & $29.4 \pm 0.8 \mathrm{ab}$ & $38.2 \pm 1.1 \mathrm{~b}$ & $40.22 \pm 1.17 \mathrm{c}$ & $59.78 \pm 1.63 a$ & $1.63 \pm 0.05 \mathrm{~b}$ \\
\hline & OM & $27.8 \pm 0.8 \mathrm{a}$ & $17.5 \pm 0.5 \mathrm{a}$ & $31.1 \pm 0.9 \mathrm{a}$ & $36.5 \pm 1.0 \mathrm{c}$ & $40.71 \pm 1.13 \mathrm{c}$ & $59.29 \pm 1.58 \mathrm{a}$ & $1.59 \pm 0.05 \mathrm{~b}$ \\
\hline & CK & $24.7 \pm 0.6 \mathrm{~b}$ & $14.4 \pm 0.4 \mathrm{~b}$ & $28.7 \pm 0.7 \mathrm{~b}$ & $42.6 \pm 1.1 \mathrm{a}$ & $42.33 \pm 1.24 \mathrm{~b}$ & $57.67 \pm 1.46 \mathrm{ab}$ & $1.72 \pm 0.06 \mathrm{ab}$ \\
\hline \multicolumn{9}{|l|}{ HA } \\
\hline \multirow{4}{*}{$>2000 \mu \mathrm{m}$} & MF & $46.7 \pm 1.2 \mathrm{ab}$ & $33.4 \pm 0.9 \mathrm{a}$ & $25.4 \pm 0.6 \mathrm{~b}$ & $12.7 \pm 0.3 \mathrm{ab}$ & $24.08 \pm 0.45 c$ & $75.92 \pm 1.91 \mathrm{~b}$ & $1.40 \pm 0.04 \mathrm{ab}$ \\
\hline & $\mathrm{RF}$ & $44.5 \pm 1.2 \mathrm{ab}$ & $31.8 \pm 0.7 \mathrm{c}$ & $27.6 \pm 0.6 \mathrm{ab}$ & $13.1 \pm 0.4 \mathrm{a}$ & $26.56 \pm 0.51 \mathrm{~b}$ & $73.44 \pm 1.83 \mathrm{c}$ & $1.40 \pm 0.04 \mathrm{ab}$ \\
\hline & OM & $41.8 \pm 1.1 \mathrm{~b}$ & $31.1 \pm 0.6 \mathrm{c}$ & $28.7 \pm 0.7 \mathrm{a}$ & $13.6 \pm 0.4 \mathrm{a}$ & $28.25 \pm 0.56 \mathrm{a}$ & $71.75 \pm 1.76 c$ & $1.34 \pm 0.02 \mathrm{~b}$ \\
\hline & CK & $50.7 \pm 1.3 \mathrm{a}$ & $32.5 \pm 0.8 \mathrm{~b}$ & $23.6 \pm 0.5 c$ & $10.5 \pm 0.2 b$ & $22.10 \pm 0.37 \mathrm{~d}$ & $77.90 \pm 1.97 \mathrm{a}$ & $1.56 \pm 0.05 a$ \\
\hline \multirow{4}{*}{$2000-200 \mu \mathrm{m}$} & MF & $34.7 \pm 0.9 \mathrm{a}$ & $29.3 \pm 0.6 \mathrm{c}$ & $25.3 \pm 0.5 b$ & $13.1 \pm 0.3 \mathrm{ab}$ & $28.33 \pm 0.73 \mathrm{~b}$ & $71.67 \pm 1.75 \mathrm{a}$ & $1.18 \pm 0.05 \mathrm{a}$ \\
\hline & RF & $32.2 \pm 0.8 \mathrm{ab}$ & $30.6 \pm 0.7 \mathrm{ab}$ & $28.0 \pm 0.7 \mathrm{a}$ & $13.6 \pm 0.3 \mathrm{ab}$ & $30.84 \pm 0.82 \mathrm{ab}$ & $69.16 \pm 1.64 \mathrm{~b}$ & $1.05 \pm 0.04 \mathrm{ab}$ \\
\hline & OM & $31.5 \pm 0.7 \mathrm{~b}$ & $31.2 \pm 0.8 \mathrm{a}$ & $28.6 \pm 0.7 \mathrm{a}$ & $14.2 \pm 0.4 \mathrm{a}$ & $31.33 \pm 0.87 \mathrm{a}$ & $68.67 \pm 1.53 \mathrm{~b}$ & $1.01 \pm 0.02 \mathrm{~b}$ \\
\hline & CK & $33.6 \pm 0.9 \mathrm{ab}$ & $31.5 \pm 0.8 \mathrm{a}$ & $27.2 \pm 0.6 \mathrm{ab}$ & $11.4 \pm 0.2 \mathrm{~b}$ & $29.47 \pm 0.77 b$ & $70.53 \pm 1.71 \mathrm{ab}$ & $1.07 \pm 0.04 \mathrm{ab}$ \\
\hline \multirow{4}{*}{$200-50 \mu \mathrm{m}$} & MF & $23.5 \pm 0.5 c$ & $28.7 \pm 0.6 \mathrm{ab}$ & $33.7 \pm 0.8 \mathrm{ab}$ & $15.6 \pm 0.5 \mathrm{a}$ & $39.23 \pm 1.10 \mathrm{a}$ & $60.77 \pm 1.27 \mathrm{~b}$ & $0.82 \pm 0.01 \mathrm{~b}$ \\
\hline & $\mathrm{RF}$ & $25.2 \pm 0.7 \mathrm{a}$ & $29.6 \pm 0.6 \mathrm{ab}$ & $32.8 \pm 0.8 \mathrm{ab}$ & $14.6 \pm 0.4 \mathrm{ab}$ & $37.44 \pm 1.04 \mathrm{ab}$ & $62.56 \pm 1.35 \mathrm{ab}$ & $0.85 \pm 0.02 \mathrm{ab}$ \\
\hline & $\mathrm{OM}$ & $25.8 \pm 0.7 \mathrm{a}$ & $30.2 \pm 0.7 \mathrm{a}$ & $31.7 \pm 0.6 \mathrm{~b}$ & $15.1 \pm 0.5 \mathrm{a}$ & $36.15 \pm 0.89 \mathrm{~b}$ & $63.85 \pm 1.46 \mathrm{a}$ & $0.85 \pm 0.02 \mathrm{ab}$ \\
\hline & CK & $24.6 \pm 0.6 \mathrm{~b}$ & $27.6 \pm 0.5 b$ & $34.5 \pm 0.9 \mathrm{a}$ & $13.7 \pm 0.3 \mathrm{~b}$ & $39.79 \pm 1.16 \mathrm{a}$ & $60.21 \pm 1.20 \mathrm{~b}$ & $0.89 \pm 0.03 \mathrm{a}$ \\
\hline \multirow{4}{*}{$50-2 \mu \mathrm{m}$} & MF & $40.3 \pm 1.1 \mathrm{~b}$ & $30.5 \pm 0.7 \mathrm{a}$ & $23.7 \pm 0.4 \mathrm{~b}$ & $14.5 \pm 0.5 \mathrm{a}$ & $25.08 \pm 0.52 \mathrm{ab}$ & $74.92 \pm 1.71 \mathrm{ab}$ & $1.32 \pm 0.03 \mathrm{~b}$ \\
\hline & $\mathrm{RF}$ & $42.6 \pm 1.2 \mathrm{ab}$ & $28.8 \pm 0.6 \mathrm{ab}$ & $25.1 \pm 0.5 \mathrm{a}$ & $13.1 \pm 0.4 \mathrm{ab}$ & $26.01 \pm 0.58 \mathrm{a}$ & $73.99 \pm 1.54 \mathrm{~b}$ & $1.48 \pm 0.04 \mathrm{ab}$ \\
\hline & $\mathrm{OM}$ & $43.5 \pm 1.2 \mathrm{ab}$ & $29.6 \pm 0.6 \mathrm{ab}$ & $25.6 \pm 0.5 \mathrm{a}$ & $13.8 \pm 0.4 \mathrm{ab}$ & $25.94 \pm 0.51 \mathrm{ab}$ & $74.06 \pm 1.67 \mathrm{ab}$ & $1.47 \pm 0.04 \mathrm{ab}$ \\
\hline & CK & $45.8 \pm 1.3 \mathrm{a}$ & $27.6 \pm 0.5 \mathrm{~b}$ & $21.6 \pm 0.3 \mathrm{c}$ & $10.5 \pm 0.2 \mathrm{~b}$ & $22.74 \pm 0.42 \mathrm{~b}$ & $77.26 \pm 1.78 \mathrm{a}$ & $1.66 \pm 0.05 \mathrm{a}$ \\
\hline \multirow{4}{*}{$2-0.1 \mu \mathrm{m}$} & MF & $40.2 \pm 1.0 \mathrm{~b}$ & $30.2 \pm 0.8 \mathrm{ab}$ & $26.1 \pm 0.7 \mathrm{a}$ & $12.7 \pm 0.4 \mathrm{ab}$ & $27.05 \pm 0.76 \mathrm{a}$ & $72.95 \pm 1.47 \mathrm{~b}$ & $1.33 \pm 0.03 \mathrm{~b}$ \\
\hline & $\mathrm{RF}$ & $42.7 \pm 1.1 \mathrm{ab}$ & $31.2 \pm 0.8 \mathrm{ab}$ & $23.5 \pm 0.6 \mathrm{~b}$ & $11.6 \pm 0.3 \mathrm{ab}$ & $24.13 \pm 0.65 \mathrm{ab}$ & $75.87 \pm 1.64 \mathrm{ab}$ & $1.37 \pm 0.04 \mathrm{ab}$ \\
\hline & $\mathrm{OM}$ & $43.5 \pm 1.3 \mathrm{a}$ & $32.5 \pm 0.9 \mathrm{a}$ & $24.3 \pm 0.6 \mathrm{~b}$ & $10.1 \pm 0.2 \mathrm{~b}$ & $24.23 \pm 0.61 \mathrm{ab}$ & $75.77 \pm 1.60 \mathrm{ab}$ & $1.34 \pm 0.03 \mathrm{~b}$ \\
\hline & CK & $41.6 \pm 1.1 \mathrm{ab}$ & $28.8 \pm 0.6 \mathrm{~b}$ & $21.7 \pm 0.4 \mathrm{c}$ & $14.9 \pm 0.6 \mathrm{a}$ & $23.56 \pm 0.54 \mathrm{~b}$ & $76.44 \pm 1.75 a$ & $1.44 \pm 0.04 \mathrm{a}$ \\
\hline
\end{tabular}

Table 2. Contribution of the different humus $\mathrm{C}$ type, aromaticity (ARO\%), alphaticity (AL\%) and alkyl/oalkyl ratio were determined by using CPMAS ${ }^{13} \mathrm{C}$ NMR of FA and HA in soil particle-size fractions under different fertilizer treatments. Values followed by different lowercase letters within a column were indicated significant difference at $p<0.05$. MF chemical fertilizer alone, $R F$ rice straw and chemical fertilizer, $O M 30 \%$ organic manure and $70 \%$ chemical fertilizer, $C K$ without fertilizer input as a control.

for $3.3 \%$ and $0.12 \%$ of humic acid C content, respectively. This results showed that higher alkyl C proportion and lower carboxylic $\mathrm{C}$ proportion of HA than that of FA in different particle-size fractions (Table 2), the reason may attribute to that HA were higher in molecular weight and contain less oxygen-containing functional groups when compared with $\mathrm{FA}^{29}$. In the previous study, the results indicated that $\mathrm{ARO} \%$ of $\mathrm{HA}$ were two or three times higher than that of $\mathrm{FA}^{30}$, in the present study, the relatively higher ARO\% of HA in 200-50 $\mu \mathrm{m}$ particle-size fraction and the relatively lower ARO\% of HA in the other particle-size fractions when compared with FA, which probably 


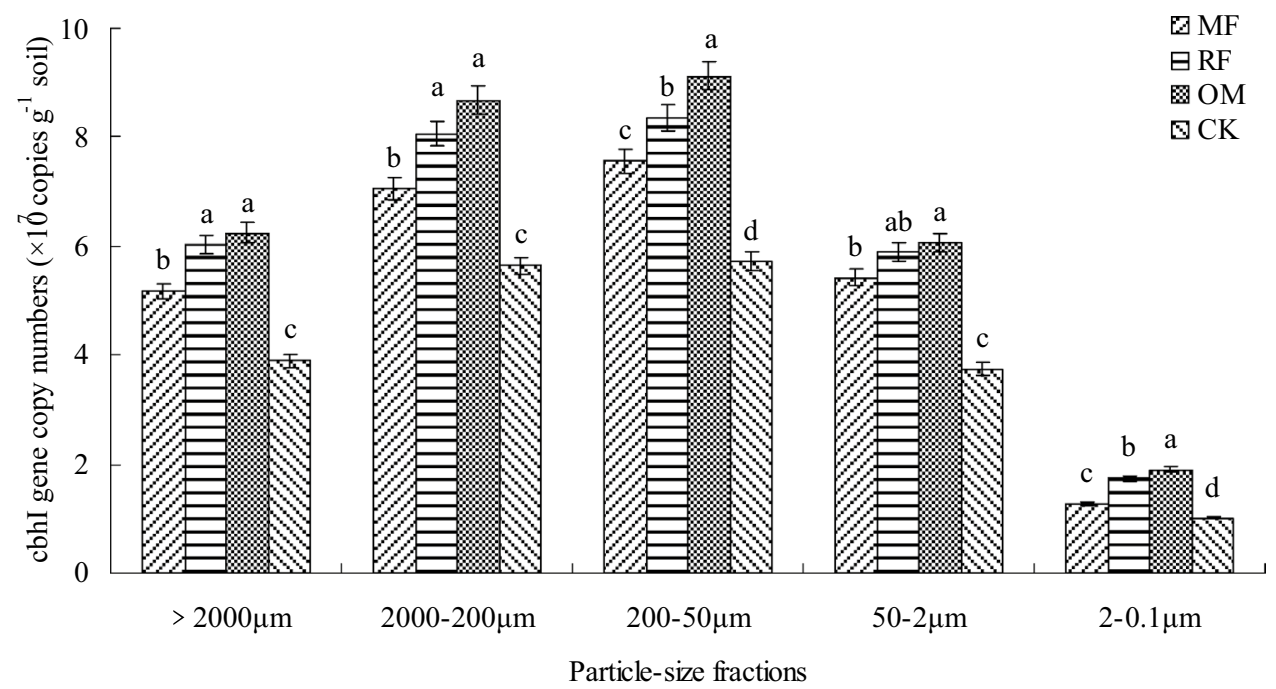

Figure 2. $c b h I$ gene copy numbers in different particle-size fractions with long-term fertilizer treatments. $M F$ chemical fertilizer alone, $R F$ rice straw and chemical fertilizer, $O M 30 \%$ organic manure and $70 \%$ chemical fertilizer, $C K$ without fertilizer input as a control. Different lowercase letters were indicated significant differences $(p<0.05)$ among different fertilizer treatments. Error bars represent standard error of the mean $(n=3)$.
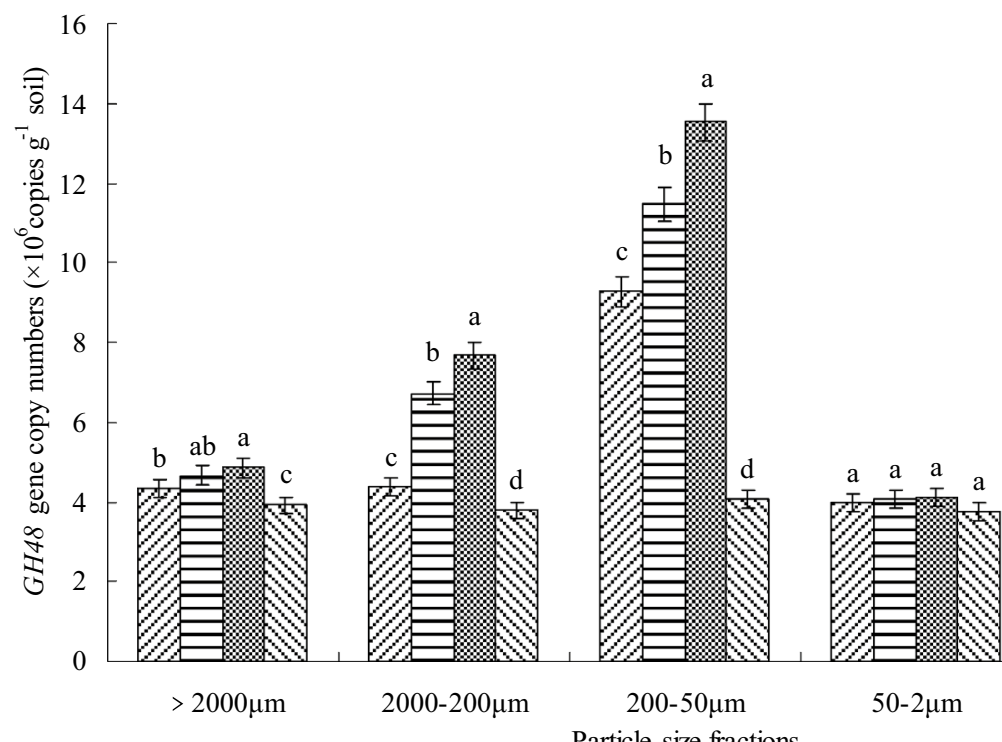

$\square \mathrm{MF}$
$\boxminus \mathrm{RF}$
$\mathrm{OMM}$
$\square \mathrm{CK}$

Figure 3. GH48 gene copy numbers in different particle-size fractions with long-term fertilizer treatments. $M F$ chemical fertilizer alone; $R F$ rice straw and chemical fertilizer; $O M 30 \%$ organic manure and $70 \%$ chemical fertilizer; $C K$ without fertilizer input as a control. Different lowercase letters were indicated significant differences $(p<0.05)$ among different fertilizer treatments. Error bars represent standard error of the mean $(n=3)$.

\begin{tabular}{|l|l|l|l|l|l|l|l|l|l|}
\hline & SOC & Total N & C/N & FA-C & HA-C & HM-C & $\beta$-glucosidase & $\beta$-cellobiohydrolase & GH48 \\
\hline$c b h I$ & $0.625^{*}$ & ns & $0.803^{* *}$ & $0.785^{*}$ & $0.758^{*}$ & 0.547 & $0.782^{*}$ & $0.796^{*}$ & $0.807^{* *}$ \\
\hline GH48 & $0.874^{* \star}$ & $0.506^{\star}$ & $0.612^{\star}$ & $0.891^{* *}$ & $0.816^{* *}$ & $0.806^{* *}$ & $0.893^{* *}$ & $0.851^{* *}$ & \\
\hline
\end{tabular}

Table 3. Correlation coefficients between soil nutrient, humic C substances, enzyme activity and abundance of $c b h I$ and $G H 48$ genes in different particle-size fractions under different fertilizer treatments. SOC soil organic carbon, $F A-C$ carbon content of fulvic acid, $H A-C$ carbon content of humic acid, $H M-C$ carbon content of humin, $n s$ no significant relationship were detected. ${ }^{*} p<0.05 ;{ }^{* *} p<0.01$. 


\begin{tabular}{|c|c|c|c|c|c|c|c|}
\hline & Alkyl C & $O$-alkyl C & Aromatic C & Carboxylic C & ARO $\%$ & AL\% & Alkyl/O-alkyl \\
\hline \multicolumn{8}{|l|}{ FA } \\
\hline$c b h I$ & ns & $0.702^{\star *}$ & ns & ns & $-0.527^{\star}$ & $0.548^{*}$ & $-0.586^{*}$ \\
\hline GH48 & ns & $0.736^{\star *}$ & ns & $-0.514^{*}$ & $-0.536^{*}$ & $0.573^{*}$ & Ns \\
\hline \multicolumn{8}{|l|}{ HA } \\
\hline$c b h I$ & $-0.735^{\star *}$ & ns & $0.568^{*}$ & $0.572^{*}$ & $0.608^{\star}$ & $-0.607^{\star}$ & $-0.705^{\star \star}$ \\
\hline GH48 & $-0.612^{\star}$ & ns & $0.545^{*}$ & ns & $0.614^{*}$ & $-0.593^{\star}$ & $-0.613^{\star}$ \\
\hline
\end{tabular}

Table 4. Correlation coefficients between chemical compositions of $\mathrm{C}$ groups of FA and HA with abundance of $c b h I$ and $G H 48$ genes in different particle-size fractions under different fertilizer treatments. $n s$ no significant relationship were detected. ${ }^{*} p<0.05 ;{ }^{* *} p<0.01$.

due to that chemical structure of different humus component might depend on the heterogeneous environment that formed in different particle-size fractions ${ }^{7}$.

In the present study, the results showed that carboxylic $C$ of FA in $50-2 \mu \mathrm{m}$ and $2-0.1 \mu \mathrm{m}$ fractions were higher than that of the other fractions $(>2000 \mu \mathrm{m}, 2000-200 \mu \mathrm{m}$ and $200-50 \mu \mathrm{m})$ (Table 2). Some results indicated the alkyl/o-alkyl C of soil FA were usually regarded as a sensitive index of SOM decomposition ${ }^{31,32}$, and the alkyl/o-alkyl C of soil FA were lower in 200-50 $\mu \mathrm{m}$ fraction but higher in $50-2 \mu \mathrm{m}$ and 2-0.1 $\mu \mathrm{m}$ fractions in this study, which were suggested that there had higher SOM decomposition in 50-2 $\mu \mathrm{m}$ and 2-0.1 $\mu \mathrm{m}$ fractions ${ }^{32}$. Meanwhile, this results indicated that dominant $\mathrm{C}$ group of HA in $200-50 \mu \mathrm{m}$ fraction were aromatic $\mathrm{C}$ and it were different from the other soil fractions that were dominated by alkyl C, thus resulting in the highest $\mathrm{AL} \%$ and lowest ARO\% in 200-50 $\mu \mathrm{m}$ fraction. Together with the lowest alkyl/o-alkyl C of HA in this fraction, these results further suggested that relatively lower humification degree in 200-50 $\mu \mathrm{m}$ fraction than that of the other fractions $^{33}$. On the contrary, alkyl/o-alkyl C of HA in $50-2 \mu \mathrm{m}$ and 2-0.1 $\mu \mathrm{m}$ fractions were higher than that of other particle-size fractions in this study, which were suggested that there were more stable organic matter and a possible accumulation of recalcitrant compound in these fractions ${ }^{20,34}$.

Cellulose-degrading enzyme plays an important role in decomposing soil microorganism, and the abundance of $c b h I$ gene were usually regarded as a suitable marker for the cellulolytic fungi ${ }^{14}$. In this study, the abundance of $c b h I$ gene were regarded as the fungal glycoside hydrolase family 7 from the Basidiomycota and Ascomycota ${ }^{10}$. Meanwhile, our results also indicated that abundance of $c b h I$ gene in different particle-size fractions were changed under long-term application of fertilization condition, and the abundance of $c b h I$ gene in different particle-size fractions were increased under combined application of crop residue and organic manure with chemical fertilizer condition (RF and OM treatments) (Fig. 2, Table 2), the reason maybe attributed to that there were more soil nutrient and $\mathrm{C}$ source with organic manure treatments, which were provide an appropriate soil environment, soil properties and nutrient for soil cellulolytic fungi multiplying ${ }^{14,32}$. However, some results indicated that abundance of cellulolytic gene were decreased under long-term application of mineral fertilizer condition ${ }^{24}$. Furthermore, the abundance of $c b h I$ gene were significant related to the content of SOC and $\mathrm{C} / \mathrm{N}$ ratio ${ }^{15}$. The lowest abundance of $c b h I$ gene and higher total $\mathrm{N}$ content were showed in $2-0.1 \mu \mathrm{m}$ particle-size fraction, thus there had no significant relationship between abundance of $c b h I$ gene and total $\mathrm{N}$ content (Table 3 ). Soil $\beta$-cellobiohydrolase and $\beta$-glucosidase activities were significant correlated with abundance of $c b h I$ gene (Table 3 ), suggested that change in abundance of these cellulolytic fungi of functional relevance in terms of C transformation in paddy ecosystem, consistent with the results of the previous studies ${ }^{24,32}$, who found that abundance of $c b h I$ gene were relatively higher in fine sand but lowest in clay fraction, were generally increased with application of organic fertilizer treatment. However, there is still need further to study relationship between the other related rhizosphere soil enzyme activity and soil $\mathrm{C}$ transformation under long-term fertilization condition.

Multicellular actinomycetes and fungi were usually regarded as efficient cellulose decomposers, and actinobacteria plays an important role in SOM turnover, breakdown of recalcitrant molecules such as cellulose and polycyclic aromatic hydrocarbons ${ }^{15,35}$. In the present study, the results showed that abundance of GH48 gene in different particle-size fractions were significant changed under long-term application of fertilization condition, were ten times lower than that abundance of $c b h I$ gene (Figs. 2, 3). The reason maybe attributed to that qPCR primers did not included all actinobacterial GH48 gene diversity from culture actinobacterial strains in the present experiment condition ${ }^{15}$. Therefore, the abundance of $G H 48$ gene in different particle-size fractions were lower, compared with abundance of $c b h I$ gene. Meanwhile, our results indicated that abundance of GH48 gene were highest in 200-50 $\mu \mathrm{m}$ fraction and lower in 50-2 $\mu \mathrm{m}$ and 2-0.1 $\mu \mathrm{m}$ fractions, and there had significant correlation between abundance of GH48 with SOC, total N contents, C/N ratio and soil cellulase activity (Table 3). The reason maybe attributed to that high $\mathrm{C} / \mathrm{N}$ ratio had negative influence on soil extracellular hydrolytic enzyme activity during litter decomposition, and soil enzyme activity synthesized by cellulolytic microbe in different particle-size fractions were increased with combined application of crop residue and organic manure with chemical fertilizer practice under lower soil $\mathrm{C} / \mathrm{N}$ ratio condition, which were consistent with the results of previous studies ${ }^{24,32}$, who found that abundance of $G H 48$ gene were relatively higher in fine sand but lowest in clay fraction, were generally increased with application of organic fertilizer condition.

In recent years, some results indicated that soil humification process is an important index of the change in amount and chemical structure of humus ${ }^{32,37}$. In the present study, the results showed that there had significant relationship between abundance of cellulolytic microbial with soil humus structural characteristic (Table 3 ). And the results also showed that $\mathrm{C}$ of $\mathrm{HA}$ were higher correlation with abundance of cellulolytic gene, suggested that $\mathrm{C}$ of $\mathrm{HA}$ were more active and sensitive to environment change than that of $\mathrm{FA}^{32,38}$. Meanwhile, there had some 
different relationship between C of FA and HA with abundance of cellulolytic gene (Table 4) for that naturally different characteristic of humus component ${ }^{39}$. In the previous study, these results indicated that o-alkyl $\mathrm{C}$ were generally considered as an easily indicator for the change of bio-decomposable organic component ${ }^{21,40}$. In this study, there had positively correlation between o-alkyl C of FA with abundance of cellulolytic gene and the negatively relationship between alkyl/o-alkyl C of HA with abundance of cellulolytic gene were confirmed that cellulose-degrading microbial community prefer the less humified fractions such as $200-50 \mu \mathrm{m}$ fraction, rather than smaller fraction especially $2-0.1 \mu \mathrm{m}$ fraction that contained more stable and recalcitrant substrate (Table 3 , Figs. 2 and 3). The alkyl C, AL\%, alkyl/o-alkyl C of HA were negatively $(p<0.05)$ correlated with both abundance of $c b h I$ and GH48 genes, and alkyl/o-alkyl C of FA had no correlation with abundance of GH48 gene (Table 4), which were consistent with the results of previous studies ${ }^{32,41}$, who found that abundance of $c b h I$ and GH48 genes had negative correlation with alkyl/O-alkyl ratio $\mathrm{C}$ of $\mathrm{HA}$, no correlation were detected between abundance of GH48 gene with alkyl/O-alkyl ratio C of FA. However, due to the different distribution of functional microbial group in soil particle-size fractions mediating soil $\mathrm{C}$ transformation by using culture-independent method, further analysis were still needed to investigate the situ expression of glucoside hydrolase gene in rhizosphere soil under long-term fertilization condition.

\section{Conclusion}

This result showed that distribution of humus carbon component (FA, HA and HM) were increased under longterm application of fertilization condition, and the FA, HA and HM C contents in $>2000 \mu \mathrm{m}$ and $200-50 \mu \mathrm{m}$ fractions with MF, RF and OM treatments were significant improved, compared without fertilizer input treatment. The results also indicated that alkyl C and oalkyl C groups of FA and HA in $>2000 \mu \mathrm{m}$ fraction with different fertilizer treatments were higher than that of the other fractions, the order of relative abundance of different $\mathrm{C}$ groups of HA in different particle-size fractions were following alkyl C $>o$-alkyl C $>$ aromatic $\mathrm{C}>$ carboxylic $\mathrm{C}$. Compared without fertilizer input treatment, the abundance of $c b h I$ and $G H 48$ genes in different particle-size fractions were increased under combined application of crop residue and organic manure with chemical fertilizer condition. There had close positive relationship between abundance of $c b h I$ and GH48 genes with chemical composition of FA and HA, which suggested that cellulolytic microorganism plays an important role in maintaining and changing chemical composition of FA and HA. However, further studies were necessary to investigate the role of soil fungi and actinobacteria in soil carbon cycling related to long-term fertilizer management.

Received: 9 February 2021; Accepted: 1 September 2021

Published online: 16 September 2021

\section{References}

1. Smith, P. et al. Review: The role of ecosystems and their management in regulating climate, and soil, water and air quality. J. Appl. Ecol. 50, 812-829 (2013).

2. O'Connor, J. J. et al. Impacts of land management practices on blue carbon stocks and greenhouse gas fluxes in coastal ecosystemsA meta-analysis. Global change Biol. 26, 1354-1366 (2020).

3. Plaza-Bonilla, D., Álvaro-Fuentes, J. \& Cantero-Martínez, C. Identifying soil organic carbon fractions sensitive to agricultural management practices. Soil Till. Res. 139, 19-22 (2014).

4. Guo, J. S. et al. Non-structural carbohydrate dynamics associated with antecedent stem water potential and air temperature in a dominant desert shrub. Plant Cell Environ. 43, 1467-1483 (2020).

5. Ling, N. et al. Response of the bacterial diversity and soil enzyme activity in particle-size fractions of Mollisol after different fertilization in a long-term experiment. Biol. Fert. Soils. 50, 901-911 (2014).

6. Lasota, J. et al. Forest humus type governs heavy metal accumulation in specific organic matter fractions. Water Air Soil Pollut. 231, 80 (2020)

7. Savarese, C. et al. Molecular characterization of soil organic matter and its extractable humic fraction from long-term field experiments under different cropping systems. Geoderma 383, 114700 (2021).

8. Reddy, S. B. et al. Soil humic and fulvic acid fractions under different land use systems. Madras Agric. J. 99, 507-510 (2012)

9. Jindo, K. et al. Influence of stability and origin of organic amendments on humification in semiarid soils. Soil Sci. Soc. Am. J. 75, 2178-2187 (2011).

10. Stursová, M. et al. Cellulose utilization in forest litter and soil: Identification of bacterial and fungal decomposers. FEMS Microbiol. Ecol. 80, 735-746 (2012).

11. Kubicek, C. P., Seidl, V. \& Seiboth, B. Plant cell wall and chitin degradation. In Cellulose and Molecular Biology of Filamentous Fungi (eds Borkovish, K. A. \& Ebbole, D. J.) 96-413 (ASM Press, 2010).

12. Ogonda, L. A. et al. Characterization and engineering of two new $G H 9$ and GH48 cellulases from a Bacillus pumilus isolated from Lake Bogoria. Biotechnol. Lett. 43, 691-700 (2021).

13. Cheng, J. M. et al. Winter warming rapidly increases carbon degradation capacities of fungal communities in tundra soil: Potential consequences on carbon stability. Mol. Ecol. 30, 926-937 (2021).

14. Weber, C. F. et al. Responses of soil cellulolytic fungal communities to elevated atmospheric $\mathrm{CO}_{2}$ are complex and variable across five ecosystems. Environ. Microbiol. 13, 2778-2793 (2011).

15. de Menezes, A. B. et al. C/N ratio drives soil actinobacterial cellobiohydrolase gene diversity. Appl. Environ. Microbiol. 81, 30163028 (2015).

16. Yeh, Y. F. et al. A metagenomic approach for the identification and cloning of an endoglucanase from rice straw compost. Gene 519, 360-366 (2013).

17. Yang, X. Y. et al. Effects of contrasting soil management regimes on total and labile soil organic carbon fractions in a loess soil in China. Geoderma 177-178, 49-56 (2012).

18. Tang, H. M. et al. Effects of long-term fertiliser regime on soil organic carbon and its labile fractions under double cropping rice system of southern China. Acta Agric. Scand. 70, 409-418 (2020).

19. Tang, H. M. et al. Long-term effects of NPK fertilizers and organic manures on soil organic carbon and carbon management index under a double-cropping rice system in Southern China. Commun. Soil Sci. Plan. 49, 1976-1989 (2018).

20. Stemmer, M., Gerzabek, M. H. \& Kandeler, E. Organic matter and enzyme activity in particle-size fractions of soils obtained after low-energy sonication. Soil Biol. Biochem. 30, 9-17 (1998). 
21. Zhang, Q. et al. Fatty-acid profiles and enzyme activities in soil particle-size fractions under long-term fertilization. Soil Sci. Soc. Am. J. 80, 97-111 (2016).

22. Pane, C. et al. Agricultural waste-based composts exhibiting suppressivity to diseases caused by the phytopathogenic soil-borne fungi Rhizoctonia solani and Sclerotinia minor. Appl. Soil Ecol. 65, 43-51 (2013).

23. Baldock, J. A. et al. Assessing the extent of decomposition of natural organic materials using solid state ${ }^{13} \mathrm{C}$ NMR spectroscopy. Aust. J. Soil Res. 35, 1061-1083 (1997).

24. Fan, F. et al. Impacts of organic and inorganic fertilizers on nitrification in a cold climate soil are linked to the bacterial ammonia oxidizer community. Microb. Ecol. 62, 982-990 (2011).

25. SAS. SAS Software of the SAS System for Windows. (SAS Institute Inc, 2008).

26. Senesi, N. \& Loffredo, E. The chemistry of soil organic matter. In Soil Physical Chemistry 2nd edn (ed. Sparks, D. L.) 239-370 (CRC Press, 1999).

27. Morales, J. et al. Degradation of carbofuran and carbofuran-derivatives in presence of humic substances under basic conditions. Chemosphere 89, 1267-1271 (2012).

28. Lehtonen, K., Hnninen, K. \& Ketola, M. Structurally bound lipids in peat humic acids. Org. Geochem. 32, 33-43 (2001).

29. Güngǒr, E. B. \& Bekbǒlet, M. Zinc release by humic and fulvic acid as influenced by pH, complexation and DOC sorption. Geoderma 159, 131-138 (2010).

30. Abakumov, E., Lodygin, E. \& Tomashunas, V. ${ }^{13} \mathrm{C}$ NMR and ESR characterization of humic substances isolated from soils of two Siberian Arctic islands. Int. J. Ecol. 3, 1-7 (2015).

31. Rosenberg, W. et al. Liming effects on the chemical composition of the organic surface layer of a mature Norway spruce stand (Picea abies [L.] Karst.). Soil Biol. Biochem. 35, 155-165 (2003).

32. Zhang, Q. et al. Evident variations of fungal and actinobacterial cellulolytic communities associated with different humified particle-size fractions in a long-term fertilizer experiment. Soil Biol. Biochem. 113, 1-13 (2017).

33. Yang, Z., Singh, B. \& Sitaula, B. Soil organic carbon fractions under different land uses in Mardi watershed of Nepal. Commun. Soil Sci. Plan. 35, 615-629 (2004).

34. Anderson, D. W. \& Paul, E. A. Organo-mineral complexes and their study by radiocarbon dating. Soil Sci. Soc. Am. J. 48, 298-301 (1984).

35. McCarthy, A. J. Lignocellulose-degrading actinomycetes. FEMS Microbiol. Rev. 46, 145-163 (1987).

36. Leitner, S. et al. Influence of litter chemistry and stoichiometry on glucan depolymerization during decomposition of beech (Fagus sylvatica L.) litter. Soil Biol. Biochem. 50, 174-187 (2012).

37. Ikeya, K., Yamamoto, S. \& Watanabe, A. Semiquantitative GC/MS analysis of thermochemolysis products of soil humic acids with various degrees of humification. Org. Geochem. 35, 583-594 (2004).

38. Shindo, H. et al. $\delta^{13} \mathrm{C}$ values of organic constituents and possible source of humic substances in Japanese volcanic ash soils. Soil Sci. 170, 175-182 (2005).

39. Li, C. L. et al. Moisture effect on soil humus characteristics in a laboratory incubation experiment. Soil Water Res. 11, 37-43 (2016).

40. Preston, C. M. \& Trofymow, J. A. Variability in litter quality and its relationship to litter decay in Canadian forests. Can. J. Bot. 78, $1269-1287$ (2000).

41. Chavez-Vergara, B. et al. Organic matter dynamics and microbial activity during decomposition of forest floor under two native neotropical oak species in a temperate deciduous forest in Mexico. Geoderma 235-236, 133-145 (2014).

\section{Acknowledgements}

This study was supported by National Natural Science Foundation of China (31872851), Innovative Research Groups of the Natural Science Foundation of Hunan Province (2019JJ10003).

\section{Author contributions}

H.T., X.X. and C.L. wrote the main manuscript text, Y.X. and K.C. prepared Figs. 1-3, W.L. and K.C. prepared Tables 1 and 2, L.S. and L.W. prepared Tables 3 and 4 . All authors reviewed the manuscript.

\section{Competing interests}

The authors declare no competing interests.

\section{Additional information}

Correspondence and requests for materials should be addressed to H.T. or Y.X.

Reprints and permissions information is available at www.nature.com/reprints.

Publisher's note Springer Nature remains neutral with regard to jurisdictional claims in published maps and institutional affiliations.

Open Access This article is licensed under a Creative Commons Attribution 4.0 International License, which permits use, sharing, adaptation, distribution and reproduction in any medium or format, as long as you give appropriate credit to the original author(s) and the source, provide a link to the Creative Commons licence, and indicate if changes were made. The images or other third party material in this article are included in the article's Creative Commons licence, unless indicated otherwise in a credit line to the material. If material is not included in the article's Creative Commons licence and your intended use is not permitted by statutory regulation or exceeds the permitted use, you will need to obtain permission directly from the copyright holder. To view a copy of this licence, visit http://creativecommons.org/licenses/by/4.0/.

(C) The Author(s) 2021 